\title{
O HABEAS CORPUS NA MIRA DA DITADURA MILITAR: Uma Análise das Transformações Legislativas entre 1964 e 1969
}

\author{
Ingrid Raíssa Carneiro do Carmo \\ Universidade Federal Rural do Semi-árido - Ufersa. Mossoró/RN, Brasil. \\ Rafael Lamera Giesta Cabral \\ Mossoró/RN, Brasil. CEP 59625-900. http://lattes.cnpq.br/8035594335420500. https://orcid.org/0000-0002-6442-4924. \\ rafaelcabral@ufersa.edu.br
}

Autor correspondente. Universidade Federal Rural do Semi-árido - Ufersa. Rua Francisco Mota Bairro, 572 - Pres. Costa e Silva.

RESUMO

O presente artigo analisa as alterações legislativas que desarticularam a concessão de habeas corpus nos primeiros anos do Regime Militar (1964-1969). Tais modificações ilustram a tentativa de legalizar o golpe e de impor uma agenda de autoritarismo, legitimando a perseguição aos opositores do regime mediante a supressão de direitos e garantias fundamentais. A partir do estudo dos Atos Institucionais no 2, 5 e 6, e da Lei de Segurança Nacional, pretende-se entender como esses mecanismos jurídicos restringiram direitos e garantias fundamentais dos cidadãos. Examinou-se, em livros, teses, reportagens jornalísticas e artigos, os fundamentos de cada alteração em consonância com o contexto de cada mudança. O exame dos habeas corpus julgados pelo Supremo Tribunal Federal nesse período permite compreender como a resistência de alguns ministros, em relação à ideologia autoritária dos militares, suscitou o endurecimento da repressão dentro da própria Corte. Conclui-se que tais modificações originaram mecanismos de contenção e repressão dos atos de oposição da ditadura militar.

Palavras-chave: Alterações legislativas; ditadura militar; habeas corpus; Supremo Tribunal Federal.

THE HABEAS CORPUS ON MILITARY DICTORSHIP:

AN ANALYSIS OF LEGISLATIVE TRANSMISSIONS BETWEEN 1964 AND 1969

ABSTRACT

This article analyzes the legislative changes that dismantled the granting of habeas corpus in the early years of the Military Regime (1964-1969). Such modifications illustrate the attempt to legalize the coup and to impose an agenda of authoritarianism, legitimizing the persecution of opponents of the regime by suppressing fundamental rights and guarantees. From the study of Institutional Acts no. 2, 5 and 6 and the National Security Law, it is intended to understand how these legal mechanisms have restricted citizens' fundamental rights and guarantees. In the books, theses, journalistic articles and articles, the foundations of each change were examined in consonance with the context of each change. The examination of habeas corpus judged by the Federal Supreme Court in this period allows us to understand how the resistance of some ministers, in relation to the authoritarian ideology of the military, led to the hardening of repression within the Court itself. It is concluded that these modifications originated mechanisms of containment and repression of the acts of opposition of the Military Dictatorship.

Keywords: Federal Supreme Court; habeas corpus; legislative changes; military dictatorship.

Recebido em: 26/6/2020

Aceito em: 1\%/2/2021 


\section{INTRODUÇÃO}

Nos últimos anos, o aumento dos clamores de parte da sociedade civil por uma intervenção militar no Brasil não pode ser ignorado. A defesa de movimentos autoritários é motivo de alerta tanto para as instituições democráticas quanto para a própria sociedade civil, que em período eleitoral tendem a ser mais suscetíveis a disputas de narrativas que nem sempre são portadoras de interesses bem compreendidos.

A ditadura militar (1964-1985) teve seu legado autoritário revisitado sob inúmeros pontos de vista. No âmbito da Justiça de Transição, como um movimento que busca encontrar caminhos para o processo de redemocratização pós-ditadura, o direito à memória e à verdade passa a ser fundamental para enfrentar as narrativas políticas produzidas pela ditadura. 0 objetivo da Justiça de Transição, além de incorporar uma reforma das instituições para a democracia e punir os violadores de direitos humanos, é produzir efeitos pedagógicos na construção de um futuro pautado em uma educação para a não repetição de atos de violência em massa. Nesse sentido, estudos que visem a fomentar na sociedade brasileira debates críticos acerca da faceta autoritária do regime militar, passam a ser essenciais para superarmos o processo de desinformação que tais disputas causam.

O tema ditadura militar é inesgotável por várias razões. As narrativas produzidas pelos vencedores, além de conterem lacunas, omitem a verdade. Com as aberturas de arquivos da ditadura, novos documentos veem à tona, possibilitando a reinterpretação de nossa história política, sobretudo a partir de documentos jurídicos, que acabaram por incorporar violações aos direitos humanos como um aspecto de uma legalidade questionável. ${ }^{1}$

Nesse aspecto, volta-se a atenção aos principais mecanismos utilizados pela ditadura para introduzir a ideologia autoritária: a suspensão de algumas garantias fundamentais, com o fito de ampliar a repressão contra os opositores do regime. Grande parte desta repressão ocorreu a partir das alterações nas hipóteses de cabimento constitucional do habeas corpus, originando novas formas de violação de direitos humanos pela ditadura.

O instituto do habeas corpus - HC - disposto na Constituição Federal de 1946, à época em vigor, era cabível "sempre que alguém sofrer ou se achar ameaçado de sofrer violência ou coação em sua liberdade de locomoção, por ilegalidade ou abuso de poder" (BRASIL, 1946). O remédio constitucional mencionado, todavia, sofreu expressivas reduções nos seus usos, tendo como escopo afastar da apreciação judicial prisões e perseguições políticas, ou até mesmo experiências de torturas, realizadas sistematicamente pelos agentes do Estado contra seus opositores.

Utilizando-se do aparato coercitivo estatal, o governo castrense, com base nos Atos Institucionais - Al $\mathrm{n}^{\circ} 2$ e 5 - alterou significativamente a competência do Judiciário no julgamento dos habeas corpus que versavam sobre a situação daqueles que eram enquadrados na Lei de Segurança Nacional, transferindo a competência do Supremo Tribunal Federal para o Superior Tribunal Militar.

Nesse sentido ver: MARQUES, Raphael Peixoto de Paula. Julgar o passado? Verdade histórica e verdade judicial na ADPF 153. Revista Jurídica da UFERSA, Mossoró, V. 2, n. 3, p. 70-86, 2018. Disponível em: <https://periodicos.ufersa.edu.br/index.php/rejur/article/view/7607>. Acesso em: 03 jan 2019. 
Na vigência do Al-5 vários casos de prisões fundamentadas no suposto cometimento de crimes políticos contra a segurança nacional ou a ordem econômica e social foram manejados sem a possibilidade de suprimir a violação a direitos dos presos políticos, muitas vezes julgados sem as regras do devido processo legal e ampla defesa.

O presente artigo reflete uma das preocupações que permeiam as violações aos direitos humanos ao tempo da ditadura militar e busca analisar as alterações no cabimento e na competência do julgamento do habeas corpus no período de 1964 a 1969. Foi desenvolvida uma pesquisa qualitativa a partir de análise de casos emblemáticos de habeas corpus julgados no período investigado, bem como no mapeamento de artigos, livros e teses de Doutorado, com o fito de nos valermos de um aprofundamento teórico para a assimilação dos impactos sociais da suspensão dos usos do habeas corpus.

Este artigo está organizado em duas seções principais. Na primeira investigou-se como os militares buscaram dar legalidade aos atos de exceção promovidos a partir do golpe de Estado. Na segunda, buscou-se mapear os usos do habeas corpus e suas transformações legislativas tanto na teoria quanto na prática, entre os anos 1964-1969.

\section{BUSCA PELA LEGALIDADE NO GOLPE MILITAR DE 1964}

O regime militar e os usos dos Atos Institucionais - Al - impuseram desafios formais à própria concepção sobre o que é uma Constituição. A manutenção da Carta Constitucional de 1946, em plena vigência do estado de exceção, não foi coincidência. A violação ao regime constitucional, considerada necessária pelos militares, tinha como meta uma proteção questionável da própria Constituição de 1946. Sabemos que Constituições por si sós são incapazes de evitar a irrupção de regimes autoritários, bem como são usualmente utilizadas por tais regimes. Assim sendo, governos que concentram o exercício do poder na figura de um governante, de maneira ilimitada e dando margem à violação de direitos fundamentais, ainda assim mantêm em vigor a Constituição nacional (BARBOSA, 2016).

Nos dizeres de Leonardo Barbosa, "isso sugere que regimes autoritários buscam construir uma narrativa de legitimação ao adotar ou mesmo manter uma determinada Constituição. Não há regime que se afirme antidemocrático, sem mais" (BARBOSA, 2016, p. 18-19).

Como via de consequência, a ditadura brasileira seria mal assimilada se a Constituição, dispositivo tradicionalmente presente no regime democrático brasileiro, ao conviver com os atos institucionais, tivesse seu papel drasticamente reduzido. Desse mesmo modo, era imperiosa a manutenção de instituições como o Congresso Nacional e o poder Judiciário, mesmo que rigidamente controladas (BARBOSA, 2016). “Esse 'hibridismo político' traduz de fato uma necessidade de legitimação da ditadura e de seu projeto político institucional, concentrado no fortalecimento do Executivo" (2016. p. 20).

É certo que governos autoritários aspiram a diferentes mecanismos para não demonstrarem suas nuances antidemocráticas. A alternativa encontrada na experiência brasileira para dar ares de democracia e legitimar arbitrariedades foi abusar de conceitos jurídicos, alargando seus sentidos e usos.

Nessa quadra, a publicação do Ato Institucional, em 9 de abril de 1964, posteriormente nomeado como Al n. 1, foi a forma encontrada - em uma potencial substituição da ideia 
de Constituição - para conferir legitimidade ao novo regime. Confirmando a vitória do movimento militar já em seu preâmbulo, intitulado como "movimento revolucionário", concentrou para si as atribuições do poder constituinte, evidenciando os primeiros sinais de que o golpe de 1964 iria valer-se do aparato judicial para legitimar suas ações. Vejamos um pequeno fragmento do Al n. 1.

[...] O que houve e continuará a haver neste momento, não só no espírito e no comportamento das classes armadas, como na opinião pública nacional, é uma autêntica revolução. A revolução se distingue de outros movimentos armados pelo fato de que nela se traduz, não o interesse e a vontade de um grupo, mas o interesse e a vontade da Nação. A revolução vitoriosa se investe no exercício do Poder Constituinte. Este se manifesta pela eleição popular ou pela revolução. Esta é a forma mais expressiva e mais radical do Poder Constituinte. Assim, a revolução vitoriosa, como Poder Constituinte, se legitima por si mesma. [...] Nela se contém a força normativa, inerente ao Poder Constituinte. Ela edita normas jurídicas sem que nisto seja limitada pela normatividade anterior à sua vitória. Os chefes da revolução, graças à ação das Forças Armadas e ao apoio inequívoco da Nação, representam o povo e em seu nome exercem o Poder Constituinte, de que o povo é o único titular. [...] A revolução vitoriosa necessita de se institucionalizar e se apressa pela sua institucionalização a limitar os plenos poderes de que efetivamente dispõe. [...] Fica, assim, bem claro que a revolução não procura legitimar-se através do Congresso. Este é que recebe deste Ato Institucional, resultante do exercício do Poder Constituinte, inerente a todas as revoluções, a sua legitimação (BRASIL, 1964a).

Destarte, tal manifestação é resultado da não previsão dos Atos Institucionais no ordenamento jurídico vigente. Para minorar o receio de se utilizar de instrumentos não previstos, a solução encontrada culmina no fato de que a revolução iria se investir no exercício do Poder Constituinte Originário para buscar a aceitação da sociedade. Em vista disso, iria lograr um complexo e suspeito êxito na produção e edição de uma normatividade supostamente compatível com as ideias revolucionárias e que permitisse que o "movimento autoritário" atendesse a seus fins, sem estar limitado pela ordem jurídica. Dessa maneira, a Constituição de 1946, essencial para garantir a aparência de legalidade do regime, deveria vigorar em paralelo aos Atos Institucionais, com as devidas alterações que estes fizessem.

O regime possuía, com o Ato Institucional, seu estatuto jurídico e, no conceito paradoxal de "revolução" e "poder constituinte", sua onipotência. Ao institucionalizar tais conceitos por meio do Ato Institucional, em que "a revolução vitoriosa, como Poder Constituinte, se legitima por si mesma" (BRASIL, 1964a), o direito buscava se remodelar em sua própria linguagem, agora estrategicamente empregada para um fim autoritário sob o verniz democrático (CARVALHO; BENVINDO, 2018, p. 115).

Apesar da busca por mecanismos de sustentação do comando castrense, é válido ressaltar que os Atos Institucionais eram normas editadas arbitrariamente, sem participação do Congresso Nacional, não havendo, dessa forma, participação popular, quer seja de forma direta, quer seja indiretamente.

A ordem jurídica existente era híbrida: vigorava a Carta Constitucional de $1946 \mathrm{com}$ as limitações impostas pelos Atos Institucionais, que eram as bases do ordenamento jurídico do regime ditatorial. 
Em outras palavras, ao lado de uma ordem de base constitucional, de caráter permanente, havia uma ordem de base institucional, de caráter transitório, que vigoraria o tempo que fosse necessário para consolidar o projeto político dos militares (COMISSÃO..., 2014, p. 935).

É notório que a ditadura de 1964, apesar das perseguições e cassações a opositores políticos do regime, das inúmeras prisões arbitrárias e da tortura instaurada nos DOI-CODIs, estava sempre buscando um mecanismo de legitimar formalmente a sua continuidade no poder (CARVALHO; BENVINDO, 2018). Em todas as ações da ditadura militar havia uma tentativa de formalizá-las a partir de uma leitura própria do ordenamento jurídico.

$\mathrm{O}$ alto índice de abertura de Inquéritos Policiais Militares - IPMs - durante a ditadura militar é bem representativo, no entanto, quando o regramento jurídico não atendesse mais às necessidades do regime, as alterações ocorriam sem maiores discussões. Os limites na possibilidade de uso do habeas corpus, por exemplo, são bem significativos.

Nos primeiros anos do novo regime foram editadas várias normas que minoraram as hipóteses de uso do $H C$, mitigando os mecanismos de defesa dos indivíduos contra coações ilegais. Essas alterações, todavia, resultaram da ação direta do Poder Constituinte, como forma de legitimar as arbitrariedades cometidas durante a ditadura militar, haja vista que estavam resguardos por um manto de legalidade. A seguir, passa-se a concentrar uma maior atenção ao habeas corpus.

\section{HABEAS CORPUS E SEUS USOS ENTRE 1964-1969}

O habeas corpus fundamenta-se em garantir a liberdade individual diante do poder do Estado, sendo imperioso ao Estado Constitucional, devido a sua função de controlar a juridicidade da ação estatal. É, dessa forma, uma ação que tutela o direito à liberdade de locomoção, sendo este seu caráter especial (MARINONI; MITIDIERO, 2018). Na lição de Pinto Ferreira, o HC sempre terá como objetivo proteger a liberdade de locomoção do indivíduo e evitar que, em épocas de deficiência do processo penal, ocorram injustiças (FERREIRA, 1988).

A Constituição do Império de 1824 vedava a prisão de alguém se não houvesse culpa formada. A positivação do habeas corpus deu-se apenas com a criação do Código de Processo Criminal de 1832, que regulou o instituto como remédio repressivo, privativo dos brasileiros, diante de constrangimentos abusivos e legais (SILVA, 2013).

A Constituição Republicana de 1891 foi responsável por constitucionalizar o instituto do habeas corpus. Dessa forma, visando à defesa dos direitos individuais, o remédio constitucional era aplicado "sempre que o indivíduo sofrer ou se achar em iminente perigo de sofrer violência ou coação, por ilegalidade ou abuso de poder" (BRASIL, 1891). ${ }^{2}$ As Constituições posteriores mantiveram a previsão do remédio constitucional com abrangência semelhante.

A Constituição de 1946, em vigor à época do golpe militar, permitia o uso do habeas corpus "sempre que alguém sofrer ou se achar ameaçado de sofrer violência ou coação em

\footnotetext{
2 Art. 72, 22, da Constituição de 1891: "Dar-se-á o habeas corpus, sempre que o indivíduo sofrer ou se achar em iminente perigo de sofrer violência ou coação por ilegalidade ou abuso de poder".
} 
sua liberdade de locomoção, por ilegalidade ou abuso de poder. Nas transgressões disciplinares, não cabe o habeas corpus" (BRASIL, 1946).

Paradoxalmente à apreciação que o habeas corpus recebeu nas primeiras Constituições republicanas, o alcance do remédio heroico foi gradativamente minorando no decorrer dos primeiros anos do regime militar, sendo suspenso pelo Ato Institucional no 5, em 1968. A restrição aos usos do habeas corpus no período do regime em questão violou garantias fundamentais individuais dos perseguidos políticos que lutavam contra as arbitrariedades promovidas pelos mentores do estado de exceção.

Após o fim do governo de Goulart, em 31 de março de 1964, o regime militar deu início a reformas estruturantes, muitas delas direcionadas a impedir resistências contra o governo. O poder Judiciário, por exemplo, entrou no foco do regime pelas constantes decisões judiciais contrárias às ações do governo. Havia, na prática, uma indefinição sobre o futuro do STF e de seus ministros. Os rumores sobre uma possível cassação dos ministros Hermes Lima e Evandro Lins e Silva, considerados ideologicamente próximos do ex-presidente Goulart, estavam na pauta, todavia, nos momentos posteriores ao golpe, a estrutura do STF, juntamente com todos os seus ministros, foi mantida.

Embora a permanência dos dois ministros tivesse sido assegurada, os jornais da época, como “O Estado de S. Paulo", pediam a sua cassação, acusando-os de comunistas. A linha dura dos militares também demonstrava desconfiança em relação à composição do STF, ${ }^{3}$ questionando a imparcialidade e o comprometimento dos ministros com a ditadura, que pressionava pela cassação dos dois ministros (MESQUITA, 2010)

À medida que o STF concedia habeas corpus em favor dos presos políticos e comunistas presos com base em Inquéritos Policiais-Militares (IPMs), crescia a desconfiança por parte da linha dura, aumentando os anseios por uma interferência na corte constitucional. Os militares desejavam que o STF adotasse a ideologia revolucionária, unificando as decisões acerca dos rumos do país, de forma a aplicar o Direito sob o novo paradigma vigente, ao passo que o STF lutava pela manutenção de sua autonomia (VALÉRIO, 2010).

Os atritos entre o STF e os militares decorriam, principalmente, da concessão de habeas corpus com base nas irregularidades nos IPMs. Devido à ânsia de punir opositores da revolução e defendê-la, era costumeiro que os inquéritos fossem apresentados com prazos além do limite, sem que houvesse uma correta tipificação do ato tido como delituoso. Os réus, muitas vezes, ficavam presos por meses sem que houvesse sido concluída a instrução criminal, desrespeitando a lei processual penal, que limitava a 60 dias prisões dessa natureza. Os IPMs, a partir de 1968, estavam cada vez mais fundamentados em discurso político e menos em conteúdo jurídico, resultando no julgamento, por parte do STF, pela inépcia da denúncia ou inexistência de crime (VALÉRIO, 2010).

\footnotetext{
Um levantamento realizado por Otavio L. S. Valério (2010) constatou que, dos 11 ministros que compunham o Supremo Tribunal Federal à época do golpe, quatro foram indicados por Juscelino Kubitschek, dois por João Goulart e um por Jânio Quadros.
} 
O HC 41.068, ${ }^{4}$ analisado em 21 de novembro de 1964, pode ser exemplificativo: o STF deferiu o pedido do paciente Milton Coelho da Graça, preso com base na Lei no $1.802 / 53$, devido ao excesso de prazo na prisão, convertendo-se em constrangimento ilegal. O ministro relator Pedro Chaves alegou que, por estar preso oficialmente desde junho de 1964, mas materialmente desde 21 de abril de 64, recolhido pelas autoridades do 40 Exército, se deveria conceder a ordem sem prejuízo da ação penal. Observa-se que a mesma fundamentação foi usada no HC 41.015, ${ }^{5}$ julgado em 2 de dezembro de 1964, com relatoria do mesmo ministro. O pedido, que teve como paciente Geraldo Lourenço Mafra e coator Auditoria Militar de Pernambuco, foi concedido "por evidente excesso de prazo", haja vista que o paciente estava "preso há mais de 120 dias, com prisão preventiva decretada pela Auditoria Militar de Pernambuco, e sem culpa formada", estando o réu preso preventivamente desde o dia 8 de junho de 1964, conforme alegou seu advogado.

A concessão de habeas corpus também se fundamentava na ausência de individualização das condutas dos presos, quando havia um único processo com vários réus, fato este que contrariava a lei penal. Embora a Constituição de 1946 assegurasse a liberdade de pensamento, diversas prisões eram baseadas no fato de o réu ser acusado de comunista ou então de ter o acusado relações com o governo de João Goulart (VALÉRIO, 2010).

O exame do HC 41.251 demonstrava que a perseguição à "ameaça comunista" teve início logo no primeiro ano do golpe. 0 paciente Djalma Maranhão ${ }^{6}$ foi preso pela Auditoria Militar de Pernambuco no dia 8 de junho de 1964, com fundamento no art. 2o, III, ${ }^{7}$ da Lei $1.802 / 53$, acusado de dirigir jornal comunista na cidade de Natal e outros fatos. O relator, Hahnemann Guimarães, em 20 de novembro de 1964, deferiu o pedido de liberdade, pois a prisão preventiva excedia o prazo estabelecido na referida lei.

Os primeiros habeas corpus ajuizados em favor de presos políticos ocorreram logo no ano de 1964, três meses após o golpe. Observa-se que, num primeiro momento, quando a coação emanasse de autoridade militar, o STF julgava-se incompetente para processar as petições de habeas corpus, sujeitando-os à exclusiva jurisdição militar. Assim, os habeas corpus deveriam ser impetrados perante a Justiça Militar. Outrossim, é válido ressaltar que, apesar da confusão da competência no julgamento do habeas corpus dos presos políticos, o STF continuava julgando procedente o pedido quando as prisões eram realizadas em dissonância com a formalidade estabelecida na lei penal, com prisões processuais excedendo o limite permitido (SANTOS, 2004).

\footnotetext{
4 Milton Coelho da Graça, com base no artigo 2ㅇ da lei 1.802/53, foi acusado de exercer atividades extremistas. Foi preso colocando Resistência, o primeiro jornal clandestino da ditadura, nas portas das casas, com a falsa notícia "Arraes Resiste".

5 O norte-riograndense Geraldo foi acusado de propaganda subversiva e incitação a crime contra a segurança nacional, com fundamentação nos artigos 11, 12 e 13 da Lei no 1.802, de 1953. Ele também consta em lista de reprimidos pela ditadura no Estado do Rio Grande do Norte.

6 Foi deputado estadual, em 1954, pelo Rio Grande do Norte, e prefeito de Natal, tendo ganhado o pleito de 1960. Após o golpe teve seu mandato de prefeito cassado, ficando preso em Natal, Fernando de Noronha e no Recife. Morreu no ano de 1971, no exílio no Uruguai.

III - mudar a ordem política ou social estabelecida na Constituição, mediante ajuda ou subsídio de Estado estrangeiro ou de organização estrangeira ou de caráter internacional;
} 
O HC 40.605, ${ }^{8}$ julgado em 29 de julho de 1964, não reconheceu o pedido de Mário Morais, remetendo-se os autos ao Superior Tribunal Militar. O relator Evandro Lins não analisou o pedido porque o "paciente estava preso à disposição da autoridade militar". Com efeito, o HC 40.587, ${ }^{9}$ julgado em julho de 1964, possui a mesma ementa, "emanando a coação de autoridade militar, compete o julgamento ao Supremo Tribunal Militar".

Conforme comentários tecidos por Otavio Valério (2010), a mudança de entendimento do STF em relação aos crimes políticos e concessão do remédio constitucional teve início em agosto de 1964. Naquele momento baseava-se não mais na autoridade que decretava a prisão, mas sim pelo tipo penal que o réu havia cometido. Desse modo, passou-se a entender que o civil que praticasse crimes comuns não estaria mais sujeito à jurisdição militar, e sim à jurisdição ordinária.

A partir de 1965, uma súmula (298 do STF) aprovada antes do início do regime militar acerou o cenário de crise entre Judiciário e governo. A súmula determinava que os civis só poderiam ser sujeitados à Justiça Militar em época de paz, e apenas nos crimes contra a segurança externa do país ou contra instituições militares. Na prática, os usos da súmula vieram a ser invocados para solucionar os conflitos entre a jurisdição da Justiça Comum e a Miliar, bem como complementar o disposto no artigo 108, §1으 da Constituição de 1946, que determinava que:

Art. 108. À Justiça Militar compete processar e julgar, nos crimes militares definidos em lei, os militares e as pessoas que thes são assemelhadas. §1으 Esse fôro especial poderá estender-se aos civis, nos casos expressos em lei, para a repressão de crimes contra a segurança externa do país ou as instituições militares (BRASIL, 1946, s/p).

No ano de 1965 o ministro Gonçalves de Oliveira julgou procedente o $\mathrm{HC} 42.392^{10} \mathrm{com}$ base na súmula mencionada, justamente por ser o paciente civil e não ter cometido crime contra a segurança externa, não estando sujeito à Justiça Militar. Já Evandro Lins, em dois julgados de outubro do mesmo ano, nos $H C s 42.515^{11}$ e $41.314,{ }^{12}$ que possuem a mesma ementa, dispunha que "o legislador ordinário só pode sujeitar civis à Justiça Militar, em tempos de paz, nos crimes contra a segurança externa do país ou às instituições militares (sum. 298)" e, nesses termos, concedeu os pedidos com base no artigo 108 da Constituição e na súmula

\footnotetext{
8 Mário Moraes foi preso sob suspeita de exercer atividade subversiva. A prisão se deu em virtude de o paciente ser percebido como um agitador comunista, secretário do Partido Comunista Brasileiro. Assim, foi detido por medida de segurança no início do movimento militar.

9 O paciente José de Moura Beleza, presidente do Sindicato dos Bancários do Ceará, foi preso e torturado durante a ditadura na ilha de Fernando de Noronha, possuindo, ainda, seu mandato sindical e direitos políticos cassados por 10 anos. Foi acusado de manter ligação com o Partido Comunista e incurso no artigo 2ㅇ, III, da Lei 1.802/53.

${ }^{10}$ Gabriel Procópio Loures, Elpidio Luiz de Souza e Joaquim Paulo de Oliveira foram acusados de possuir ligação com o movimento operário e sindicalista, em organizações político-militares tidas como comunistas.

${ }^{11}$ Os pacientes Rayl Peçanha Bezerra, Arthur Martins Filho, Manoel Martins e Afonso Celso Nogueira Monteiro foram indiciados com base no IPM instaurado na loteria estadual e na Caixa Econômica do Rio de Janeiro, que visava a apurar possível ligação deles com o Partido Comunista Brasileiro e atos de corrupção, com a entrega das economias fluminenses aos subversivos.

12 Paulo Devanier Lauda, Adelmo Simas Genro, Euclydes Gonçalves e José Bivvá Larré foram acusados de terem participado e contribuído para a criação do chamado "Grupo dos Onze", ordem que apoiaria as ideias de Leonel Brizola, as reformas de base e o programa do Partido Trabalhista Brasileiro.
} 
citada. É interessante que, mesmo com os militares no comando do país, e com os crescentes pedidos de intervenção no STF, a Corte procurou manter sua independência, não cedendo às pressões militares. Essa postura é corroborada pela posição do ministro Evandro Lins, no Habeas Corpus 42.515, em continuar concedendo os habeas corpus mesmo quando a autoridade coatora fosse militar, sob a alegação de que:

A diferença que existe, exatamente, entre o regime democrático e os regimes totalitários, é que naquele se assegura a os cidadãos direitos e garantias, entre os quais se encontra o de serem julgados perante a Justiça competente, com ampla defesa, enquanto nos países totalitários o indivíduo não goza de garantias constitucionais semelhantes e está sujeito ao arbítrio da ditadura dominante (BRASIL, 1965, p. 6).

A nova jurisprudência do STF assegurava a concessão do habeas corpus quando a prisão processual excedesse o prazo legal, como ocorreu no $H C 41.901,{ }^{13}$ de 1965 , ou quando o acusado da prática de crime comum estivesse submetido à jurisdição militar. A posição do Tribunal incomodava cada vez mais os militares.

Como reação à posição contrária do STF à ideologia do governo, foi expedido pelo marechal Castello Branco o Ato Institucional no 2 - Al-2 - em 1965. Como manifestação exclusiva do Poder Constituinte, sob a vigência da Carta de 1946, o Ato Institucional no 2 trouxe em seu preâmbulo que "a revolução está viva e não retrocede. Tem promovido reformas e vai continuar a empreendê-las, insistindo patrioticamente em seus propósitos de recuperação econômica, financeira, política e moral do Brasil. Para isto precisa de tranquilidade. ${ }^{14 \prime \prime}$

A edição dessa nova medida foi a alternativa encontrada pelos militares para, com base na retórica de promover uma reforma na Suprema Corte ante o congestionamento de pautas, aumentar a influência dos militares no STF, indicando ministros alinhados com os militares e minorando a influência dos ministros que votavam em dissonância com os interesses da "revolução". Mais uma vez o regime de exceção brasileiro valeu-se do aparato legal como forma de garantir a legitimidade do governo perante a sociedade civil.

Com efeito, em seu artigo 60 e parágrafos subsequentes, o Al-2 alterou para 16 o número de ministros que compunham o Supremo Tribunal Federal (STF):

Art. 60 - Os arts. 94, 98, 103 e 105 da Constituição passam a vigorar com a seguinte redação:

"Art. 98 - O Supremo Tribunal Federal, com sede na Capital da República e jurisdição em todo o território nacional, compor-se-á de dezesseis Ministros.

\footnotetext{
${ }^{13}$ EMENTA: Excesso de prazo em prisão preventiva. O acusado por isso deve responder solto ao processo a que está submetido. Observa-se que o paciente, o alemão Thomas Maack, ainda não havia sido indiciado por nenhum crime. Foi preso acusado de subversão e de planejar a instalação do regime comunista no país, pois, no início da década de 60 , enquanto estudante, participou dos movimentos estudantil e trotskista, embora já não estivesse vinculado a tais movimentos quando foi preso. Maack também fez oposição ao golpe militar dentro da FMUSP, quando já era professor na instituição.

${ }^{14}$ BRASIL. Ato Institucional n. 2. Brasília, 1965..
} 


\section{Democracia}

Parágrafo único - O Tribunal funcionará em Plenário e dividido em três Turmas de cinco Ministros cada uma. ${ }^{15 "}$

Art. 105 - Os Juízes Federais serão nomeados pelo Presidente da República dentre cinco cidadãos indicados na forma da lei pelo Supremo Tribunal Federal. [...]

§3ㅇ - Aos Juízes Federais compete processar e julgar em primeira instância.

e) os crimes políticos e os praticados em detrimento de bens, serviços ou interesse da União ou de suas entidades autárquicas, ressalvada a competência da Justiça Militar e da Justiça Eleitoral;

h) os habeas corpus em matéria criminal de sua competência ou quando a coação provier de autoridade federal não subordinada a órgão superior da Justiça da União. ${ }^{16}$

Para a Comissão Nacional da Verdade, tais alterações resultaram do intuito dos militares em estabelecer a ideologia do regime à magistratura federal de primeira instância e a burocracia do regime, haja vista que competia à magistratura federal a atribuição de julgar os crimes políticos e aqueles praticados em detrimento de bens, serviços ou interesse da União ou de suas entidades autárquicas, os $\mathrm{HC}$ em matéria criminal que Ihes eram cabíveis ou quando oriundos de autoridade federal que não estava subordinada aos órgãos superiores da Justiça da União (COMISSÃO..., 2014).

O Al-2, em seu artigo 14, proclamava que "ficam suspensas as garantias constitucionais ou legais de vitaliciedade, inamovibilidade e estabilidade, bem como a de exercício em funções por tempo certo. ${ }^{17 \prime}$ Por outro lado, já no artigo 19, inciso I, ficava assegurado que, "os atos praticados pelo Comando Supremo da Revolução e pelo Governo Federal, com fundamento no Ato Institucional de 9 de abril de 1964, no presente Ato Institucional e nos atos complementares deste ficarão excluídos de apreciação judicial. ${ }^{18 \prime}$

O Ato Institucional determinava também que a competência de julgamento dos crimes contra a segurança nacional caberia à Justiça Militar, modificando o §1으 do artigo 108 da Constituição de 1946. Dessa forma, estariam sujeitos à jurisdição militar aqueles que atentassem contra a segurança externa e nacional. Os crimes mencionados estavam expressos na Lei de Segurança Nacional (Lei 1.802/53), que definia as condutas que atentavam contra o Estado e a Ordem Pública e Social. Tal modificação legislativa veio para revogar a Súmula 298 do STF, que estava sendo usada como fundamento para a concessão de diversos habeas corpus por incompetência da Justiça castrense para julgamento das ações, permitindo o aumento da repressão aos "subversivos" enquadrados na Lei de Segurança Nacional.

\footnotetext{
${ }^{15}$ Em relação às atribuições das turmas e do plenário, a Emenda 16/65 veio disciplinar: Art. 5o ao art. 101 são acrescidos os seguintes parágrafos: “§1을 Incumbe ao Tribunal Pleno o julgamento; a) das causas de competência originária de que trata o inciso I, com exceção das previstas na alínea $h$, a menos que se trate de medida requerida contra ato do Presidente da República, dos Ministros de Estado, da Câmara dos Deputados, do Senado Federal e do próprio Supremo Tribunal Federal; b) das prejudiciais de inconstitucionalidade suscitadas pelas Turmas; c) dos recursos interpostos de decisões das Turmas, se divergirem entre si na interpretação do direito federal; d) dos recursos ordinários nos crimes políticos (inciso II, c); e) das revisões criminais (inciso IV); f) dos recursos que as Turmas decidirem submeter ao Plenário do Tribunal. §2ㅇ Incumbe às Turmas o julgamento definitivo das matérias enumeradas nos incisos I, $h$ (com a ressalva prevista na alínea $a$ do parágrafo anterior), II, $a$ e $b$, e III, dêste artigo, e distribuídas na forma da lei".

${ }^{16}$ BRASIL. Ato Institucional n. 2. Brasília, 1965.

17 BRASIL. Ato Institucional n. 2. Brasília, 1965.

18 BRASIL. Ato Institucional n. 2. Brasília, 1965
} 
Outrossim, o Al-2 estabeleceu a necessidade de um julgamento prévio, por parte do Superior Tribunal Militar (STM), antes da análise do STF, quando fossem ajuizados habeas corpus por acusados de cometer crimes contra a segurança nacional. Competia à Justiça Militar a realização dos inquéritos e aplicação das punições (BECHARA; RODRIGUES, 2015).

Destarte, como os habeas corpus não eram mais apreciados de início pelo Supremo Tribunal Federal, devendo passar, primeiro, por todas as instâncias do STM, o STF fixou uma nova jurisprudência, pois seria necessária uma análise primária, por parte do STM, para que a Corte pudesse dar prosseguimento no julgamento de um habeas corpus em caso de crimes políticos. A necessidade de uma prévia análise por parte do STM ensejou a negação de vários habeas corpus por parte do Supremo, mesmo em casos de descumprimento do prazo máximo de prisão processual, consolidando uma nova jurisprudência a partir de 1968 (VALÉRIO, 2010).

Os efeitos do Al-2 no STF foram imediatos. Ainda em dezembro de 1965, com menos de dois meses da vigência da nova medida do governo militar, foi julgado prejudicado o $H C$ $42.758,{ }^{19}$ com relatoria do ministro Evandro Lins, sob o fundamento do deslocamento da competência para a Justiça Militar.

A legislação editada pelos militares reduziu as competências e atuações do poder Judiciário, intervindo na competência e autonomia do STF e, por consequência, restringindo direitos e garantias fundamentais dos cidadãos. Nesta senda, as ações do Estado para garantir a continuidade da autoproclamada revolução eram apreciadas de maneira errática pelo Judiciário, devido às diversas alterações promovidas (BECHARA; RODRIGUES, 2015).

Conforme assevera o relatório da CNV:

[...] durante o regime militar, num processo iniciado em 1964 e concluído em 1969, restringiu-se, de um lado, o acesso ao poder Judiciário, ao impedir-se o controle judicial sobre determinadas matérias; de outro, possibilitou-se a interferência, pelo presidente da República, na estrutura e na composição das instituições judiciárias, mediante criação e extinção de cargos e aposentadoria de magistrados (COMISSÃO..., 2014, p. 937).

Os pedidos de habeas corpus agora eram julgados prejudicados devido ao ato editado. O Al-2 teve sua força normativa reconhecida pelo STF, e, a partir de 1966, com base na alteração do artigo 108, modificou novamente sua jurisprudência, raramente concedendo habeas corpus sem a análise prévia do STM. Nota-se, entretanto, que, até 1968, continuava a ser julgada procedente a expedição de habeas corpus fundamentados no excesso de prazo da prisão realizada durante o processo, mesmo após a entrada dos novos ministros indicados pelos presidentes militares. Tal fato, todavia, ocorria somente após anuência do STM (VALÉRIO, 2010).

Um novo entendimento do STF foi fixado em 1966, com base na Lei 1.802/53, que vedava, em seu artigo 9:

\footnotetext{
${ }^{19}$ Manoel Alves Ribeiro foi acusado de subversão e de possuir ligações com o Partido Comunista Brasileiro, sendo incurso no art. 2ํ, III, da Lei 1.802/53. Mimo, como era conhecido, ficou quatro meses escondido no sótão da sua casa, na rua José Boiteux, para fugir dos militares.
} 
[...] a reorganização ou tentativa de reorganizar de fato ou de direito, pondo logo em funcionamento efetivo, ainda que sob falso nome ou forma simulada, partido político ou associação dissolvidos por força de disposição legal ou fazê-lo funcionar nas mesmas condições quando legalmente suspenso (BRASIL, 1953).

Desse modo, os habeas corpus eram concedidos quando os partidos não eram formalmente constituídos, ou quando havia somente mobilização para que o Partido Comunista fosse legalizado, mantendo o entendimento de que só haveria crime quando o funcionamento do partido fosse efetivado (VALÉRIO, 2010). Esse foi o posicionamento adotado no julgamento do $H C 43.734,{ }^{20}$ em que o relator, ministro Luiz Gallotti, com base nos artigos 9o e $10^{21} \mathrm{da}$ Lei n-1.802/53, afirmou que, "supõe, portanto, a lei, nos dois referidos artigos, que o partido tenha sido organizado, registrado, e, depois, dissolvido ou suspenso". Como se pode observar, não existia justa causa para a sua condenação com base na Lei $n=1.802 / 53$, dado que o paciente acusado de tentar reorganizar o Partido Operário Trotskista não o consolidou e nem o registrou.

A Carta Constitucional de 1967 apresentou novamente a previsão do habeas corpus, e manteve a repressão aos crimes contra a segurança nacional ou contra instituições militares, mas mantendo a competência da Justiça Militar. Preservou, também, a possibilidade de recurso ao Supremo contra as decisões do Superior Tribunal Militar em casos de crimes contra a segurança nacional. A nova Constituição teve como escopo constitucionalizar as medidas provenientes do Al-2, não alterando o posicionamento do STF em relação à concessão de habeas corpus, que continuava a conceder a maior parte dos pedidos (SANTOS, 2004).

Neste diapasão, o ministro Adalício Nogueira, relator do HC 44.751, julgado em 6 de dezembro de 1967, deu provimento ao recurso, pois entendeu que a ação criminosa dos acusados, que respondiam por crimes tipificados na Lei no $1.802 / 53$, não havia sido delimitada. Não havia justa causa para a ação penal, pois não existia especificação dos atos praticados pelos pacientes, impossibilitando a defesa dos acusados, havendo apenas a alegação de que "os denunciados, deliberados e conscientemente, atentaram contra a segurança nacional, tentaram mudar a ordem política e social estabelecida na Constituição, colocando em prática, inequivocamente, os métodos internacionais comunistas" e de que "os professores promoveram a comunicação e subversão do amanhã, incutindo na mente dos jovens ideias perigosas e dissolventes".

A posteriori, a edição do Decreto-Lei 314/67 veio a alterar a Lei 1.802/53, que definia os crimes contra o Estado e a Ordem Pública e Social, em seu artigo 2으, IV, como sendo a tentativa de "subverter, por meios violentos, a ordem política e social, com o fim de estabelecer ditadura de classe social, de grupo ou de indivíduo.22" A nova lei veio para determinar o que

\footnotetext{
${ }^{20}$ Henrique de Carvalho Matos foi acusado de reorganizar o extinto Partido Operário Trotskista.

${ }^{21}$ Art. 9o Reorganizar ou tentar reorganizar, de fato ou de direito, pondo logo em funcionamento efetivo, ainda que sob falso nome ou forma simulada, partido político ou associação dissolvidos por fôrça de disposição legal ou fazê-lo funcionar nas mesmas condições quando legalmente suspenso. Pena: - reclusão de 2 a 5 anos; reduzida da metade, quando se tratar da segunda parte do artigo. Parágrafo único. A concessão do registro do novo partido, uma vez passada em julgado, porá imediatamente termo a qualquer processo ou pena com fundamento neste artigo. Art. 10‥ Filiar-se ou ajudar com serviços ou donativos, ostensiva ou clandestinamente, mas sempre de maneira inequívoca, a qualquer das entidades reconstituídas ou em funcionamento na forma do artigo anterior. Pena: - reclusão de 1 a 4 anos.

22 BRASIL. Lei no 1.802. Rio de Janeiro, 1953.
} 
seria a "segurança nacional", retirando do seu texto a expressão "por meios violentos", permitindo uma maior adequação dos seus artigos à ideologia do governo, objetivando que o Supremo cessasse a concessão de habeas corpus àqueles que não faziam uso de "meios violentos". Desse modo, todos os atos percebidos como subversivos eram passíveis de prisão ou processo penal (SANTOS, 2004).

A edição do Decreto-Lei 314/67, todavia, não logrou êxito, como esperavam os militares, alterando minimamente as decisões do STF, eis que pelo princípio da anterioridade penal, nullum crimen nulla poena sine praevia lege poenali, a prática de crime depende de lei penal anterior à conduta do agente. Dessa forma, a Lei de Segurança Nacional não poderia ser aplicada aos "subversivos" apoiadores de João Goulart antes de sua edição. A manutenção do prazo máximo de 60 dias para a prisão processual continuava a fundamentar a concessão de habeas corpus pelo STF quando este limite era excedido. Observa-se que houve, também, um aumento no número de habeas corpus concedidos sob a alegação de ausência de justa causa para a ação penal, provavelmente em decorrência do enrijecimento da repressão militar decorrente do crescimento da luta armada por grupos de esquerda (VALÉRIO, 2010).

O caráter legalista, característica dos primeiros anos do governo ditatorial, foi progressivamente minorado (BARBOSA, 2016). Dessa forma, com a expedição do Ato Institucional no 5, de 13 de dezembro de 1968, o mais rígido dos atos editados, o Executivo ficou cada vez mais fortalecido em depreciação dos demais poderes, que tiveram o exercício de suas atribuições criticamente comprometido. Era atribuição do chefe do Executivo decretar recesso parlamentar, bem como legislar em todas as matérias. Poderia, também, ignorando as limitações expressas na Constituição, decretar intervenção nos Estados e municípios e suspender direitos políticos de qualquer cidadão pelo prazo de dez anos.

Ademais, uma das medidas mais severas, decorrente do Al-5, foi a suspensão do habeas corpus nos casos de crimes políticos contra a segurança nacional, a ordem econômica e social, bem como a economia popular. ${ }^{23} \mathrm{Com}$ essa medida, que privou o cidadão de instrumento primordial para a defesa de sua liberdade, objetivava-se desarticular os grupos de oposição ao governo ditatorial, enrijecendo o tratamento jurídico dispensado aos presos considerados subversivos (BERNARDO; COSTA, 2014).

O STF, à época, não atuaria mais em processos relacionados à atividade política nacional, não podendo exercer controle de legalidade dos atos do Executivo, excluídos de apreciação judicial, e nem proteger os direitos e garantias individuais.

O regramento excepcional criado pelo Regime Militar praticamente impossibilitava a defesa dos presos políticos, pois nada pode ferir mais a luta pela defesa da liberdade do que o fim de seu melhor instrumento, seu remédio heroico, o habeas corpus. Eu próprio vivi intensamente os anos da ditadura e sou testemunha ocular dessa recente história, em que as liberdades e outros tantos direitos fundamentais estiveram rompidos, impedindo que o exercício da advocacia pudesse ser realizado de maneira livre, pois havia até mesmo a incomunicabilidade do preso em relação ao advogado, disciplinada pela lei! (LINS e SILVA, 2014).

\footnotetext{
${ }^{23}$ HC 46.803 - Ementa: Recurso de habeas corpus. Apurado pelas informações ministradas pela autoridade tida como coatora que o recolhimento do paciente deflui de indiciamento em crime contra a segurança nacional, descabe o conhecimento do habeas corpus. Aplicação do Ato Institucional n 5, artigo 10‥ Recurso não provido
} 
Em janeiro de 1969 o governo expediu um decreto permitindo a cassação e a aposentadoria de forma compulsória, com base no Ato Institucional no 5 , durante as férias do Judiciário, de três ministros do Supremo que manifestavam costumeiramente decisões favoráveis aos presos políticos, em desacordo com os ideais revolucionários. Os ministros eram Evandro Lins e Silva, Hermes Lima e Vitor Nunes Leal. Em protesto contra a medida do então presidente da República, o marechal Artur da Costa e Silva, outros dois ministros pediram aposentadoria, Gonçalves de Oliveira e Lafayette de Andrada.

Em relação ao Al-5, a Comissão Nacional da Verdade aduz que:

No sistema de justiça do regime inaugurado em 1964, o protagonismo em tudo que dissesse respeito aos crimes contra a segurança nacional passou a ser, depois do Al-5, da Justiça Militar. Isso significou submeter as pessoas acusadas de crimes previstos no artigo 10 으 do Al-5 ao julgamento por juízes que tendiam a orientar-se por aquilo que julgavam ser interessante, conveniente e oportuno para a dita 'revolução' (COMISSÃO... , 2014, p. 956).

O Ato Institucional no 6, publicado em 1969, retomou o número de ministros para 11, modificando o artigo 114, II, $a$, da Constituição de 1967, não mais permitindo a apreciação de habeas corpus pelo STF quando estes fossem ajuizados como substitutos do recurso ordinário, objetivando a redução na burocracia e acelerando o julgamento. ${ }^{24} \mathrm{Em}$ seu preâmbulo, justificava-se a intervenção do Executivo no Judiciário:

O PRESIDENTE DA REPÚBLICA, CONSIDERANDO que, como decorre do Ato Institucional no 5, de 13 de dezembro de 1968, a revolução brasileira reafirmou não se haver exaurido o seu poder constituinte, cuja ação continua e continuará em toda sua plenitude, para atingir os ideais superiores do movimento revolucionário e consolidar a sua obra; CONSIDERANDO que, como órgão máximo do poder Judiciário, o Supremo Tribunal Federal é uma instituição de ordem constitucional, recebendo da Lei Maior, devidamente definidas, sua estrutura, atribuições e competências; CONSIDERANDO haver o governo, que ainda detém o poder constituinte, admitido, por conveniência da própria Justiça, a necessidade de modificar a composição e de alterar a competência do Supremo Tribunal Federal, visando a fortalecer sua posição de Corte eminentemente constitucional e, reduzindo-lhes os encargos, facilitar o exercício de suas atribuições; CONSIDERANDO que as pessoas atingidas pelas sanções políticas e administrativas do processo revolucionário devem ter igualdade de tratamento sob o império das normas institucionais e demais regras legais delas decorrentes. ${ }^{25}$

Após esses dois Atos Institucionais, o STF passou a negar a concessão de habeas corpus, com base na alteração no artigo 114, que estivessem relacionados ou não com a Lei de Segurança Nacional. A nova jurisprudência do STF consolidou o disposto no artigo 10으 do Al-5, negando uma grande parte dos habeas corpus envolvendo acusados de crimes contra a segurança nacional. Apesar de continuar presente a fundamentação da concessão de habeas corpus até então utilizada, não havia mais o dispositivo costumeiramente utilizado, assim sen-

\footnotetext{
${ }^{24}$ HC 47.125 - EMENTA: Habeas Corpus. Suspensão da garantia de habeas corpus, nos crimes contra a segurança nacional, a ordem econômica e social e a economia popular art. 10 do Ato Institucional n. 5, de. 13.12.1968. Não pode ser substituído por pedido originário o recurso da decisão denegatória de habeas corpus - art. 114, ii, a, da Constituição, com a redação do ato n. 6, de. 1.2.1969. Habeas corpus não conhecido.

${ }^{25}$ BRASIL. Ato Institucional n. 6. Brasília, 1969.
} 
do, não era mais concedido o remédio constitucional com base no excesso do prazo da prisão processual, apesar de ainda em vigor a Lei de Segurança Nacional que estabeleceu o limite de 60 dias (VALÉRIO, 2010).

Os Atos Institucionais no 5 e no 6 foram responsáveis por acabar com a resistência do STF em relação ao golpe, interrompendo a concessão de habeas corpus àqueles que lutavam contra o regime. A legislação constitucional e infraconstitucional, bem como o Supremo Tribunal Federal estavam perfeitamente enquadrados nos ideais do regime autoritário instaurado em 1964.

Na literatura jurídica o período de resistência do STF contra o governo militar acaba sendo focado nas atividades dos três ministros que foram cassados e aposentados pelo regime. Por outro lado, é também comum observar que essa resistência nunca foi estabelecida de forma ampla. A conivência do Judiciário com o regime de exceção é um fato inquestionável, como também é o fato de, na transição para a democracia, não ter empreendido reformas institucionais para dar uma interpretação conforme à Constituição de 1988 (CABRAL, 2017).

\section{CONCLUSÃO}

Consoante o aludido, observa-se que o regime de exceção caracterizou-se pela mitigação das hipóteses de cabimento do habeas corpus, representando a expansão do autoritarismo dos militares, cerceando liberdades políticas e individuais, possibilitando as violações de direitos humanos dos perseguidos politicamente, impondo severas perdas para a história democrática do país.

A análise referente às hipóteses de cabimento do habeas corpus compreendeu o período de junho de 1964, com a concessão do instituto aos primeiros opositores do regime, e terminando em 1969, com a outorga do Al-6.

A partir da abordagem realizada foi possível compreender que a legitimação do regime castrense ocorreu mediante a manutenção de instituições democráticas e a adaptação do ordenamento jurídico aos ideais revolucionários que operaram em plena contradição aos próprios ideais democráticos. Dessa forma, a tentativa de disfarçar as arbitrariedades cometidas pelo governo militar deu-se desde o início da tomada do poder, com a expedição do Ato Institucional no 1, objetivando dar ares de legitimidade aos atos dos militares, investindo-os no exercício do Poder Constituinte.

Assim sendo, os atos subsequentes editados vieram para amoldar, de maneira gradativa, o Judiciário à retórica militar. No curso do regime ditatorial, o Supremo Tribunal Federal se pronunciou sobre a violação dos direitos e garantias fundamentais, mediante a concessão de habeas corpus em favor dos acusados de terem cometido crimes políticos. Esse posicionamento, iniciado logo nos primeiros meses após o golpe, acarretou descontentamentos por parte dos militares e seus aliados, que pediam o afastamento dos ministros simpatizantes do pensamento de João Goulart.

A solução encontrada, disfarçando a tentativa de controle da Suprema Corte por parte dos militares foi a outorga do Al-2, excluindo de apreciação judicial as ações do Comando Revolucionário, tornando o Judiciário impossibilitado de analisar os atos do regime, legalizando a violação de direitos dos opositores do regime. Ademais, o Al-2 alterou tanto a estrutura 
como a jurisprudência do STF concernente à concessão de habeas corpus, estabelecendo a prévia análise por parte do STM antes da apreciação pelo STF.

Foi também com o Al-2 que a Justiça Militar se consolidou como defensora da ditadura, passando a ter a competência de processar e julgar os civis enquadrados em crimes contra a segurança nacional. Tal fato corroborou a institucionalização da repressão arbitrária dos perseguidos políticos, facilitando as mais diversas formas de violação de seus direitos fundamentais.

Outrossim, o Al-5, o mais severo dos atos institucionais, consolidou o poder da linha dura militar. Pôs fim à resistência de alguns ministros, alterando a realidade do Supremo, cassando seus ministros, controlando a autonomia da Corte e cessando com a possibilidade de concessão de habeas corpus quando o réu estivesse sendo acusado de cometer crimes contra a segurança nacional, a ordem econômica e social e a economia popular.

Em relação à evolução da jurisprudência do STF sobre a concessão de habeas corpus, três foram os principais posicionamentos observados com as mudanças realizadas: inicialmente, os pedidos em que a autoridade coatora fosse militar não eram concedidos; posteriormente, passou-se a conceder grande parte dos HC fundados no excesso de prazo da prisão processual, e, por fim, com a vigência do Al-5, o STF tornou-se incompetente para processar e julgar os habeas corpus impetrados pelos presos políticos.

Nesta senda, a presente pesquisa concluiu que as diversas legislações editadas pelo Comando Revolucionário permitiram que o Estado privasse o cidadão da proteção contra o arbítrio dos agentes públicos, legitimando a perseguição de parte da sociedade civil contrária ao regime autoritário. Assim, a elaboração dos Atos Institucionais estava focada em inovar o ordenamento jurídico, possibilitando a punição dos revoltosos, enrijecendo a disciplina jurídica que lhes era conferida.

A análise da História permite que possamos compreender as nuances de uma determinada época, configurando um legítimo direito de um povo se reconhecer pelo passado. Por conseguinte, os limites impostos ao conhecimento da totalidade dos fatos de uma dada sociedade são problemáticos em diversos aspectos, eis que o entendimento de experiências anteriores permite a construção da identidade de cada indivíduo.

Uma nova ordem jurídica deve ter o ideal de justiça como um de seus princípios basilares, garantindo a manutenção do Estado Democrático de Direito, afastado da atual experiência democrática os atos de exceção cometidos no passado, garantindo a preservação dos direitos de cada cidadão.

Por conseguinte, urge a necessidade da instituição de uma efetiva Justiça de Transição, ${ }^{26}$ em todos os seus pilares - direito à memória e à verdade, direito à reparação das vítimas, persecução criminal dos perpetradores de direitos humanos e reforma institucional - que lide com o legado autoritário da ditadura militar. Conhecer, reconhecer e punir os abusos cometidos pelos agentes do Estado, reparar a vítimas e reformar as instituições públicas é mister para que a ditadura militar de 64 seja, finalmente, superada nos mais amplos aspectos.

\footnotetext{
${ }^{26}$ Para maiores esclarecimentos sobre o tema da Justiça de Transição, recomenda-se a leitura dos seguintes textos: CABRAL, Rafael Lamera. Reforma das instituições para a democracia e o legado autoritário: a branda Justiça de Transição no Brasil. Revista Direitos fundamentais \& Democracia, Curitiba, v. 22, n. 3, 2017; MARQUES, Raphael Peixoto de Paula. Julgar o passado? Verdade histórica e verdade judicial na ADPF 153. Revista Jurídica da Ufersa, v. 2, n. 3, 2018.
} 


\section{REFERÊNCIAS}

ARAÚJO, Maria Paula; SILVA, Izabel Pimentel da; SANTOS, Desirre dos Reis. Ditadura militar e democracia no Brasil: historia, imagem e testemunho. 1. ed. Rio de Janeiro: Ponteio, 2013. Disponível em: http://www.justica. gov.br/central-de-conteudo/anistia/anexos/ditadura-militar-_-versao-final.pdf/@@download/file/Ditadura\%20 militar._.\%20Vers\%C3\%A3o\%20final.pdf. Acesso em: 11 jan. 2019.

BARBOSA, Leonardo Augusto de Andrade. História constitucional brasileira: mudança constitucional, autoritarismo e democracia no Brasil Pós-1964. 2. ed. Brasília: Câmara dos Deputados; Edições Câmara, 2016. V. 1.

BECHARA, Gabriela Natacha; RODRIGUES, Horácio Wanderlei Rodrigues. Ditadura militar, atos institucionais e Poder Judiciário. Justiça do Direito (UPF), v. 29, p. 587-605, 2015. Disponível em: http://www.seer.upf.br/index. php/rjd/article/download/5611/3826/. Acesso em: 11 jan. 2019.

BERNARDO, R. S.; COSTA, R. J. C. Habeas Corpus sob enfoque histórico: a disciplina conferida ao remédio constitucional durante o Regime Militar. Revista Acadêmica da ESMP-CE, v. 1, p. 1-16, 2014. Disponível em: http://tmp. mpce.mp.br/esmp/publicacoes/Edital-02-2014/2-Rosa-Juliana-Cavalcante-Costa_Rosangela-Souza-Bernardo. pdf. Acesso em: 11 jan. 2019.

BRASIL. Ato Institucional n. 2, de 27 de outubro de 1965. Mantém a Constituição Federal de 1946, as Constituições Estaduais e as respectivas Emendas, com as alterações introduzidas pelo Poder Constituinte originário da Revolução de 31.3.1964, e dá outras providências. In: Diário Oficial da República Federativa do Brasil, Brasília, DF, 02 27. 1965. Disponível em: http://www.planalto.gov.br/ccivil_03/AIT/ait-02-65.htm. Acesso em: 11 jan. 2019.

BRASIL. Ato Institucional n. 1, de 9 de abril de 1964. Dispõe sobre a manutenção da Constituição Federal de 1946 e as Constituições Estaduais e respectivas Emendas, com as modificações introduzidas pelo Poder Constituinte originário da revolução Vitoriosa. In: Diário Oficial da República Federativa do Brasil, Rio de Janeiro, RJ, 9 abr. 1964a. Disponível em: http://www.planalto.gov.br/ccivil_03/AIT/ait-01-64.htm. Acesso em: 11 jan. 2019.

BRASIL. Ato Institucional n. 6, de 10 de fevereiro de 1969. Altera a composição e competência do Supremo Tribunal Federal, amplia disposição do Ato Institucional no 5, de 13 de dezembro de 1968 e ratifica as emendas constitucionais feitas por Atos Complementares. In: Diário Oficial da República Federativa do Brasil, Brasília, DF, 1 fev.1969. Disponível em: http://www.planalto.gov.br/ccivil_03/AIT/ait-06-69.htm. Acesso em: 11 jan. 2019.

BRASIL. Ato Institucional n. 5, de 13 de dezembro de 1968. São mantidas a Constituição de 24 de janeiro de 1967 e as Constituições Estaduais. O Presidente da República poderá decretar a intervenção nos estados e municípios, sem as limitações previstas na Constituição, suspender os direitos políticos de quaisquer cidadãos pelo prazo de 10 anos e cassar mandatos eletivos federais, estaduais e municipais, e dá outras providências. In: Diário Oficial da República Federativa do Brasil, Brasília, DF, 13 dez. 1968. Disponível em: http://www.planalto.gov.br/CClVil_03/AIT/ait-05-68.htm. Acesso em: 11 jan. 2019.

BRASIL. Constituição dos Estados Unidos do Brasil, 18 de setembro de 1946. A Mesa da Assembléia Constituinte promulga a Constituição dos Estados Unidos do Brasil e o Ato das Disposições Constitucionais Transitórias, nos termos dos seus arts. 218 e 36, respectivamente, e manda a todas as autoridades, às quais couber o conhecimento e a execução desses atos, que os executem e façam executar e observar fiel e inteiramente como neles se contêm. In: Diário Oficial da União, Rio de Janeiro, 18 set. 1946. Disponível em: http://www.planalto.gov.br/ ccivil_03/Constituicao/Constituicao46.htm. Acesso em: 11 jan. 2019.

BRASIL. Constituição dos Estados Unidos do Brasil, de 24 de fevereiro de 1891. Nós, os representantes do povo brasileiro, reunidos em Congresso Constituinte, para organizar um regime livre e democrático, estabelecemos, decretamos e promulgamos a seguinte In: Diário Oficial da União, Rio de Janeiro, 24 fev. 1891. Disponível em: http://www.planalto.gov.br/ccivil_03/Constituicao/Constituicao91.htm. Acesso em: 11 jan. 2019.

BRASIL. Lei no 1.802, de 5 de janeiro de 1953. Define os crimes contra o Estado e a Ordem Política e Social, e dá outras providências. In: Diário Oficial da União, Rio de Janeiro, RJ, 5 jan. 1953. Disponível em: http://www2.camara.leg.br/legin/fed/lei/1950-1959/lei-1802-5-janeiro-1953-367324-publicacaooriginal-1-pl.html. Acesso em: 11 jan. 2019.

BRASIL. Supremo Tribunal Federal. Habeas Corpus no 40.587. Paciente: José de Moura Beleza. Relator: Evandro Lins. Brasília, 29 de julho de 1964b. Disponível em: http://redir.stf.jus.br/paginadorpub/paginador.jsp?docTP=AC\&doclD=57471. Acesso em: 26 nov. 2018.

BRASIL. Supremo Tribunal Federal. Habeas Corpus no 40.605. Paciente: Mário Moraes. Relator: Evandro Lins. Brasília, 29 de junho de 1964c. Disponível em: http://redir.stf.jus.br/paginadorpub/paginador.jsp?docTP=AC\&docID=57486. Acesso em: 26 nov. 2018. 
BRASIL. Supremo Tribunal Federal. Habeas Corpus no 41.015. Paciente: Geraldo Lourenço Mafra. Relator: Pedro Chaves. Brasília, 2 de dezembro de 1964d. Disponível em: http://redir.stf.jus.br/paginadorpub/paginador.jsp?docTP=AC\&docID=57789. Acesso em: 26 nov. 2018.

BRASIL. Supremo Tribunal Federal. Habeas Corpus no 41.068. Paciente: Milton Coelho da Graça. Relator: Pedro Chaves. Brasília, 25 de novembro de 1964e. Disponível em: http://redir.stf.jus.br/paginadorpub/paginador.jsp?docTP=AC\&docID=57841. Acesso em: 26 nov. 2018.

BRASIL. Supremo Tribunal Federal. Habeas Corpus no 41.251. Paciente: Djalma Maranhão. Relator: Hahnemann Guimarães. Brasília, 30 de novembro de 1964f. Disponível em: http://redir.stf.jus.br/paginadorpub/paginador. jsp?docTP=AC\&docID=57960. Acesso em: 26 nov. 2018.

BRASIL. Supremo Tribunal Federal. Habeas Corpus no 41.314. Pacientes: Paulo Devanier Lauda, Adelmo Simas Genro, Euclydes Gonçalves e José Bivvá Larré. Relator: Evandro Lins. Brasília, 25 de outubro de 1965a. Disponível em: http://redir.stf.jus.br/paginadorpub/paginador.jsp?docTP=AC\&docID=58002. Acesso em: 26 nov. 2018.

BRASIL. Supremo Tribunal Federal. Habeas Corpus no 41.901. Pacientes: Thomas Maack. Relator: Cândido Motta, 14 de dezembro de 1965b. Disponível em: http://redir.stf.jus.br/paginadorpub/paginador.jsp?docTP=AC\&docID=90695. Acesso em: 26 nov. 2018.

BRASIL. Supremo Tribunal Federal. Habeas Corpus no 42.392. Pacientes: Gabriel Procópio Loures, Elpidio Luiz de Souza e Joaquim Paulo de Oliveira. Relator: Gonçalves de Oliveira. Brasília, 25 de agosto de 1965c. Disponível em: http://redir.stf.jus.br/paginadorpub/paginador.jsp?docTP=AC\&doclD=58354. Acesso em: 26 nov. 2018.

BRASIL. Supremo Tribunal Federal. Habeas Corpus no 42.515. Pacientes: Rayl Peçanha Bezerra, Arthur Martins FiIho, Manoel Martins e Afonso Celso Nogueira Monteiro. Relator: Evandro Lins. Brasília, 14 de outubro de $1965 \mathrm{~d}$. Disponível em: http://redir.stf.jus.br/paginadorpub/paginador.jsp?docTP=AC\&doclD=58439. Acesso em: 26 nov. 2018.

BRASIL. Supremo Tribunal Federal. Habeas Corpus no 42.758. Pacientes: Manoel Alves Ribeiro. Relator: Evandro Lins. Brasília, 2 de dezembro de 1965e. Disponível em: http://redir.stf.jus.br/paginadorpub/paginador.jsp?doc$T P=A C \&$ doc $I D=58626$. Acesso em: 26 nov. 2018.

BRASIL. Supremo Tribunal Federal. Habeas Corpus no 43.734. Pacientes: Henrique de Carvalho Matos. Relator: Luiz Gallotti, 25 de novembro de 1966. Disponível em: http://redir.stf.jus.br/paginadorpub/paginador.jsp?doc$T P=A C \&$ doc $I D=59236$. Acesso em: 26 nov. 2018.

BRASIL. Supremo Tribunal Federal. Habeas Corpus no 44.751. Pacientes: Fernando Magalhães e outra. Relator: Adalício Nogueira. Brasília, 17 de outubro de 1967. Disponível em: http://redir.stf.jus.br/paginadorpub/paginador.jsp?docTP=AC\&docID=91618. Acesso em: 26 nov. 2018.

CABRAL, Rafael Lamera. Reforma das instituições para a democracia e o legado autoritário: a branda Justiça de Transição no Brasil. Revista Direitos Fundamentais \& Democracia, Curitiba, v. 22, n. 3, p. 84-108, 2017. Disponível em: https://doi.org/10.25192/issn.1982-0496.rdfd.v22i3936. Acesso em: 2 jan. 2019.

CARVALHO, Ângelo Gamba Prata de; BENVINDO, Juliano Zaiden. Os "imperativos da revolução de março" e a fundamentação da ditadura. Revista Direito e Práxis, Rio de Janeiro, v. 9, n. 1, p. 113-145, 2018. Disponível em: http://www.scielo.br/pdf/rdp/v9n1/2179-8966-rdp-9-1-113.pdf. Acesso em: 11 jan. 2019.

COMISSÃO NACIONAL DA VERDADE - CNV. Relatório Comissão Nacional da Verdade. Recurso eletrônico. Brasília: CNV, 2014. Disponível em: http://cnv.memoriasreveladas.gov.br/. Acesso em: 20 ago. 2018.

FERREIRA, Pinto. Teoria e prática do habeas corpus. 4. ed. São Paulo: Saraiva, 1988.

LINS e SILVA, Técio. Advogados tiveram papel fundamental na resistência à ditadura. Consultor Jurídico. São Paulo, 31 mar. 2014. Disponível em: http://www.conjur.com.br/2014-mar-31/tecio-lins-silva-advogadosforamfundamentais-resistencia-ditadura. Acesso em: 20 ago.2018.

MARINONI, Luiz Guilherme; MITIDIERO, Daniel. Ações constitucionais. In: SARLET, Ingo Wolfgang; MARINONI, Luiz Guilherme; MITIDIERO, Daniel. Curso de Direito Constitucional. São Paulo: Saraiva Jur, 2018.

MARQUES, Raphael Peixoto de Paula. Julgar o passado? Verdade histórica e verdade judicial na ADPF 153. Revista Jurídica da Ufersa, Mossoró, v. 2, n. 3, p. 70-86, 2018. Disponível em: https://periodicos.ufersa.edu.br/index. php/rejur/article/view/7607. Acesso em: 3 jan. 2019.

MESQUITA. Clarissa F. M. Evandro Lins e Silva e a ditadura militar - jurisprudência de 1968. 2010. (Trabalho de Conclusão de Curso) - Escola de Formação da Sociedade Brasileira de Direito Público - SBDP, São Paulo, 2010. Disponível em: http://www.sbdp.org.br/wp/wp-content/uploads/2018/04/3_monografia-EF-2003-Evandro-Lins-e-Silva-e-a-ditadura-militar-Clarissa-Mesquita.pdf. Acesso em: 11 jan. 2019.

SANTOS, Fabrícia Cristina de Sá. O Supremo Tribunal Federal e os processos de habeas corpus (1964-1969). Revista Projeto História do Programa de Pós-Graduação de História da PUC-SP, v. 29, n. 1, p. 325-335, 2004. Disponível em: http://revistas.pucsp.br/index.php/revph/article/download/9963/7402. Acesso em: 11 jan. 2019. 
SILVA, João Pereira da. O habeas corpus e os resquícios da ditadura. São Paulo: Iglu, 2013.

SPIELER, Paula; QUEIROZ, Rafael Mafei Rabelo. Advocacia em tempos difíceis: ditadura militar 1964-1985. Curitiba: Edição do Autor, 2013.

VALÉRIO, Otávio Lucas Solano. A toga e a farda: o Supremo Tribunal Federal e o regime militar (1964-1969). 2010. Tese (Doutorado) - Universidade de São Paulo. Disponível em: http://www.teses.usp.br/teses/disponiveis/2/2139/tde-16082011-164739/pt-br.php. Acesso em: 11 jan. 2019. 